\section{Commentary: There is no "I" in team. Regionalization in thoracic surgery, the interdependence of the team, and surgical volume}

\author{
Moishe Liberman, $\mathrm{MD}, \mathrm{PhD}$
}

Regionalization in thoracic surgery involves the concentration of surgical services in high-volume centers with the goal of concentrating human and technical resources, reducing costs, and most importantly improving cancer-specific and overall outcomes. The impact of regionalization has been previously shown to not be related to one specific person's technical abilities but relies more on the team. ${ }^{1-3}$ This team involves multiple specialties, health care professionals, and technical resources to provide high-quality, efficient, and appropriate thoracic surgical oncology care with optimal outcomes.

The manuscript by Darling ${ }^{4}$ in this issue of the Journal describes the well thought-out, methodic, and patient-care driven decisions and process in the province of Ontario, Canada, which were taken to attempt to provide the most appropriate care for patients with thoracic surgical problems. The Province of Ontario should be congratulated for their well thought-out and implemented regionalization scheme and its evaluation.

While I agree that the team is more important than volume, they are intertwined and codependent. We must remember that attracting specialists to a hospital center requires volume and case mix. Maintenance of competence also requires volume and case mix. On-call coverage requires a critical mass of surgeons, which depends on surgical volume. Dealing with complex surgical complications (tracheoesophageal fistula after esophagectomy, postoperative bronchopleural fistula, acute respiratory distress syndrome following pneumonectomy, etc) requires a certain

From the Division of Thoracic Surgery, Department of Surgery, University of Montréal, Montréal, Québec, Canada.

Disclosures: The author reported no conflicts of interest.

The Journal policy requires editors and reviewers to disclose conflicts of interest and to decline handling or reviewing manuscripts for which they may have a conflict of interest. The editors and reviewers of this article have no conflicts of interest.

Received for publication June 8, 2020; revisions received June 8, 2020; accepted for publication June 9, 2020; available ahead of print June 26, 2020.

Address for reprints: Moishe Liberman, MD, PhD, Division of Thoracic Surgery, Centre Hospitalier de l'Université de Montréal, Centre de Recherche du CHUM, Room R04.402-1 900 Rue Saint-Denis, Montreal, Quebec, Canada H2X 0A9 (E-mail: moishe.liberman@umontreal.ca).

J Thorac Cardiovasc Surg 2021;161:330-1

$0022-5223 / \$ 36.00$

Copyright (c) 2020 by The American Association for Thoracic Surgery

https://doi.org/10.1016/j.jtcvs.2020.06.046

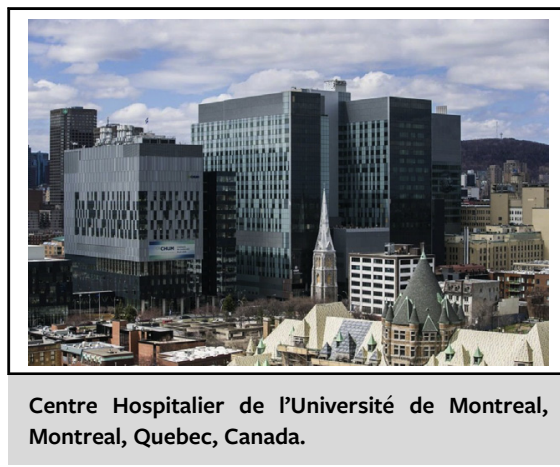

CENTRAL MESSAGE

While an experienced team is probably more important than volume alone in thoracic surgery, if there is no volume, how do you build an experienced team?

volume. Decision making and technical maintenance of competence in patients who may benefit from a bronchoplastic procedure as opposed to a pneumonectomy requires sufficient volume of these types of cases. There is no team if there is no volume!

The argument that "patients like to be treated close to home" does not cut it anymore in an era of telemedicine and interhospital partnerships and cooperation. At our hospital center in Montreal, Quebec (Centre hospitalier de l'Université de Montréal [CHUM]), most patients who, for example, need an esophagectomy for cancer who live far from Montreal will be first seen by telemedicine by the thoracic surgeon, all tests (computed tomography, positron emission tomography, esophagoscopy, biopsy, etc) will be performed at their local center or at a center closer to home, they will come to Montreal once to meet the surgeon and do their endoscopic ultrasonographic staging, and then they will receive neoadjuvant treatment (if necessary) at their local center coordinated by our esophageal cancer team at the CHUM. They will have preoperative testing close to home and then will come to Montreal for their esophagectomy. Following surgery and hospitalization, they will be followed by their local team at their local hospital with coordination through the esophageal cancer team at the CHUM. Where there is a will, there is a way. Patients can be treated at specialized centers for complex diseases far from home with minimal displacement if the coordination is there. 
There is a lot of politics when it comes to regionalization. Surgeons and surgical teams are not happy to give up a part of their practice and skill set as hospitals become regionalized. We must be sensitive to these issues and help to alleviate these frustrations. But, at the end of the day, it should be the patient who comes first. How many of us would order the foie gras at a restaurant that sold fewer than 10 orders of foie gras a year?

\section{References}

1. Birkmeyer JD, Siewers AE, Finlayson EV, Stukel TA, Lucas FL, Batista I, et al Hospital volume and surgical mortality in the United States. $N$ Engl J Med. 2002;346:1128-37.

2. Birkmeyer JD, Stukel TA, Siewers AE, Goodney PP, Wennberg DE, Lucas FL. Surgeon volume and operative mortality in the United States. N Engl J Med. 2003:349:2117-23.

3. Bendzsak AM, Baxter NN, Darling GE, Austin PC, Urbach DR. Regionalization and outcomes of lung cancer surgery in Ontario, Canada. J Clin Oncol. 2017;35:2772-80.

4. Darling G. Regionalization in thoracic surgery: the importance of the team. $J$ Thorac Cardiovasc Surg. 2021;161:323-9.
See Article page 323.

\section{Commentary: Going beyond the volume-outcomes concept: The case for regionalization in thoracic surgery}

\author{
Yaron Shargall, MD
}

How do we improve patients' outcomes? This question continues to challenge surgeons and nonsurgeons alike. A wellestablished dogma is that greater volumes, performed by specific surgeons or a center, will lead to improvement in outcome. Some convincing analyses have established this concept, ${ }^{1}$ which was later validated by other observations in North America and beyond. ${ }^{2}$ In thoracic surgery, there is some evidence that greater volumes might lead to a better outcome, ${ }^{3}$ but this concept was challenged by other observations, and no standardization exists. Moreover, volumes are not all that matters, and there is no clear definition as to what is the minimal number of resections below which a thoracic surgeon will compromise patients' outcomes. The concept of regionalization is not new and was proposed

\footnotetext{
From the Division of Thoracic Surgery, Department of Surgery, McMaster University, Hamilton, Ontario, Canada.

Disclosures: The author reported no conflicts of interest.

The Journal policy requires editors and reviewers to disclose conflicts of interest and to decline handling or reviewing manuscripts for which they may have a conflict of interest. The editors and reviewers of this article have no conflicts of interest.

Received for publication Sept 15, 2020; revisions received Sept 15, 2020; accepted for publication Sept 16, 2020; available ahead of print Sept 18, 2020.

Address for reprints: Yaron Shargall, MD, St Joseph's Healthcare Hamilton, 50 Charlton Ave East, Juravinski Tower T-2105, Hamilton, Ontario L8N 4A6, Canada (E-mail: shargal@mcmaster.ca).

J Thorac Cardiovasc Surg 2021;161:331-2

$0022-5223 / \$ 36.00$

Copyright (c) 2020 by The American Association for Thoracic Surgery

https://doi.org/10.1016/j.jtcvs.2020.09.062
}

Check for updates

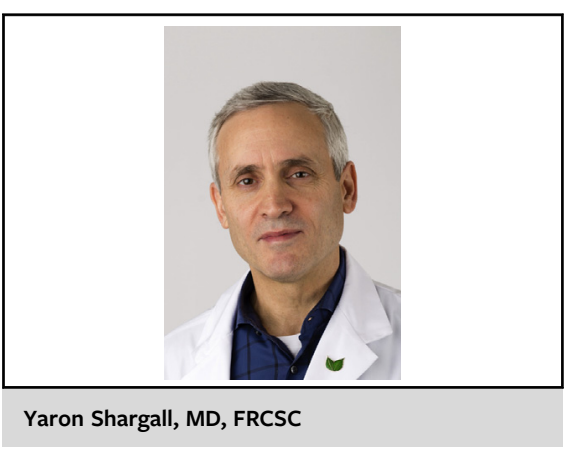

CENTRAL MESSAGE

Regionalization in thoracic surgery seems to be associated with better patient outcomes, unrelated to increase in surgeon/ hospital volumes.

before, although implementation has been, for the most part, sporadic and not well analyzed. The province of Ontario in Canada has identified the need for regionalization, performed many in-depth systematic review-based analyses, and then implemented it in thoracic, vascular, and hepatobiliary surgery and has since been instrumental in maintaining quality outcome measurements and validating them. ${ }^{4}$

In this review at the Journal, Dr Darling, who had a major role in this initiative and continues to oversee it, is providing us with convincing evidence as to the benefits of that approach. ${ }^{5}$ In Ontario, it is feasible, associated with better outcomes, can be monitored with clear quality assurance parameters, and leads to widespread best-standard care for our patients, combined with a real multidisciplinary team approach. Having experienced that move first hand, I am 